\title{
Micronucleus test in fish for in situ evaluation of the Sinos River water quality, in Brazil
}

\author{
Leonardo Airton Ressel Simões' \\ Thaís Dalzochio" \\ Angélica Goldoni"I \\ Mateus Santos de Souzalv \\ Gabriela Zimmermann Prado Rodrigues $\vee$ \\ Ismael Evandro PetryvI \\ Günther Gehlen VII \\ Luciano Basso da SilvaVIII
}

\section{Abstract}

The Sinos River basin is impacted by industrial and agricultural activities, as well as by low rates of urban wastewater treatment. The purpose of this study was to monitor de Sinos River water quality using the micronucleus test in fish and the analysis of water physicochemical parameters. Bryconamericus iheringii specimens were captured in December 2013 (summer) and July 2014 (winter) at two sites located in the Sinos River: Caraá, in the upper section of the basin, and Parobé, in the middle section. After capture, animals were immediately killed and blood samples were collected for the micronucleus test. No significant differences were observed in micronucleus frequencies between sites and sampling periods. However, in the summer, nuclear abnormalities frequencies observed in Parobé were significantly higher than in Caraá. A higher frequency of nuclear abnormalities was also found in fish captured in Caraá during winter, in comparison with frequencies found in the summer. The results for the water physicochemical analysis showed values of total phosphorous, aluminum, lead, copper and iron above the allowed limits established by the Brazilian legislation. The nuclear abnormalities induction found in the present study may be associated to the presence of cytogenotoxic substances in the water.

Keywords: Water pollution; Genotoxicity; Bryconamericus iheringii 


\section{Introduction}

The Sinos River basin, located in the northeast region of the state of Rio Grande do Sul, Brazil (FIGUEIREDO et al., 2010), extends over $3.800 \mathrm{~km}^{2}$, corresponding to $1.5 \%$ of the total state area. The Sinos River constitutes its main water course, with $190 \mathrm{~km}$ of extension (FEPAM, 1999), and despite it is heavily impacted, it provides drinking water for 1.2 million people (FIGUEIREDO et al., 2010).

Aquatic environments receive a great variety of organic and inorganic substances from natural of anthropogenic sources, which can induce damages in the aquatic biota at molecular, biochemical and physiological levels (RAND, 1995). Environmental biomonitoring studies, especially using biomarker analysis in organisms exposed in situ to pollutants, provide tools for the identification of conditions capable of causing damages to human health and the aquatic biota (SILVA et al., 2003).

Biological assays are able to characterize the effects caused by contaminants through chronic and/or acute exposure, without the previous knowledge of the chemical substances in the water (OHE et al., 2004). Several studies have used genotoxicity tests as tools for investigating the quality of underground and surface waters (HOSHINA et al., 2008; DALZOCHIO et al., 2017; LIMA et al., 2018). The micronucleus test is considered an advantageous technique with a relatively simple analysis (UDROIU, 2006) and is widely used for the monitoring of genotoxic damages in populations exposed to mutagenic and carcinogenic substances. Micronuclei may be formed by chromosome fragments or whole chromosomes that are not incorporated by the main nucleus during cell division (AL-SABTI and METCALFE, 1995). Therefore, the micronucleus test detects clastogenic and aneugenic agents (BRUNETTI et al., 1988). Several mechanisms are involved in micronuclei formation, such as chromosome breaks and errors in the mitotic spindle. In addition, the concomitant analysis of the occurrence of erythrocyte nuclear anomalies allows the evaluation of another toxicity biomarker (PACHECO and SANTOS, 1998; VIEIRA et al., 2016).

Fish are considered adequate for the monitoring of genotoxins present in water because they are able to metabolize and accumulate xenobiotics (FLORA et al., 1993). The Bryconamericus genus (Characidae: Teleostei) includes small-sized fish, with no more than $10 \mathrm{~cm}$ of length, that live in different environments and are omnivorous, constituting an important food source for other fish (BRITSKI et al., 1988). The species Bryconamericus iheringii (Boulenger, 1887) is widely distributed in the Sinos River basin and is one of the most abundant species in this water resource (COSTA and SCHULZ, 2010).

Therefore, the purpose of this study was to monitor the water quality of two sites with different rates of anthropic pressure in the Sinos River, using the micronucleus test in $B$. iheringii and the analysis of water physicochemical parameters.

\section{Material and Methods}

Samplings were conducted in December 2013 (summer) and July 2014 (winter). Fish were captured at two sites in the Sinos River: the first is located in Caraá municipality (2943'26” S 5016'46” W), in the upper section of the basin, in a region with small agricultural properties near the river spring, whereas the second site is located in Parobé municipality, approximately $4 \mathrm{~km}$ downstream the mouth of Paranhana River (29 $41^{\prime}$ '05” S 5050' 52" $\mathrm{W})$, in the middle section of the basin, in an urbanized and industrialized region.

Ten specimens of $B$. iheringii were captured at each site in both sampling periods weighing approximately $4.9 \mathrm{~g}$ and measuring $7.2 \mathrm{~cm}$. After capture, fish were immediately killed and blood samples were obtained from the caudal vein to perform the smear. The material was transported to the laboratory, where samples were fixed in absolute ethanol and stained with 5\% Giemsa. All slides were coded and analyzed in an optical microscope, considering the analysis of 2000 erythrocytes for each animal.

Surface water samples were simultaneously collected for the evaluation of the following physicochemical parameters: biochemical oxygen demand $\left(\mathrm{BOD}_{5}\right)$, chemical oxygen demand $(\mathrm{COD})\left(\mathrm{mgO}_{2} / \mathrm{L}\right)$, total phosphorous $(\mathrm{mg} / \mathrm{L})$, ammoniacal nitrogen $(\mathrm{mg} / \mathrm{L})$, suspended solids $(\mathrm{mg} / \mathrm{L})$, aluminum $(\mathrm{mg} / \mathrm{L})$, lead $(\mathrm{mg} / \mathrm{L})$, copper $(\mathrm{mg} / \mathrm{L})$, total chromium $(\mathrm{mg} / \mathrm{L})$, iron $(\mathrm{mg} / \mathrm{L})$, nickel $(\mathrm{mg} / \mathrm{L})$ and zinc $(\mathrm{mg} / \mathrm{L})$. Water analysis was performed according to the methodology described in Standard Methods for the Examination of Water and Wastewater (APHA, 2005). The results were compared to the reference values described in the Resolution 357/2005 by CONAMA (Environment National Council) for Class 1 waters (BRASIL, 2005).

Precipitation data from the 30 days previous to each sampling were obtained using a mobile meteorological station (Davis Vantage PRO 2 VP USB NS) for Caraá. For Parobé, data from the closest meteorological station $(50 \mathrm{~km})$, located in Taquara, were obtained, using the WS2812 station in the Faculdades Integradas de Taquara (FACCAT, 2014).

For the comparison of cytogenetic damages between sampling sites and periods, the Mann-Whitney test was used. All analyses were performed using the Statistical Package for the Social Sciences - SPSS 22 considering a significance level of $\mathrm{p} \leq 0.05$.

\section{Results and Discussions}

Among the techniques used to evaluate mutagenic effects in situ, the micronucleus test is frequently applied due to its easy methodology and low cost, particularly in studies considering fish as bioindicators (UDROIU, 2006; GOLDONI et al., 2014). The evaluation of micronuclei frequencies in freshwater fish allows the detection of DNA damage due to urban, industrial, heavy metals and pesticide discharges (BOLOGNESI and HAYASHI, 2011). In the present study, no significant differences 
were observed in micronucleus frequencies between sampling periods at the same site, as well as between sites in the same sampling period (Table 1). It is important to highlight that the spontaneous baseline frequency for micronuclei in fish is generally low and presents great interspecific variability, with mean values ranging from 0 to 1 micronuclei per 1000 cells (BOLOGNESI and HAYASHI, 2011). Therefore, the frequencies found in the present study (ranging from 0.00 to 0.05 ) may be considered as a baseline frequency variation for these populations of $B$. iheringii. Similarly, Bühler et al. (2012) have also observed low micronuclei frequencies $(0.29 \%)$ in the same fish species collected at a non-polluted site. The absence of significant differences between sampling sites and sampling periods suggests that the analyzed specimens are not exposed to mutagenic agents.

Table 1 - Micronuclei frequencies per 1000 cells (mean \pm standard deviation) observerd in B. iheringii captured in December 2013 (summer) and July 2014 (winter) in two sampling sites in the Sinos River.

\begin{tabular}{cccc}
\hline Site & Summer & Winter & $\mathrm{p}$ \\
\hline Caraá & $0.05 \pm 0.15$ & $0.00 \pm 0.00$ & 0.34 \\
Parobé & $0.05 \pm 0.15$ & $0.04 \pm 0.14$ & 0.94 \\
$p$ & 1.00 & 0.38 & \\
\hline
\end{tabular}

Data are expressed as mean \pm standard deviation.

The assessment of nuclear abnormalities frequencies is considered complementary to the micronuclei analysis, considering that these anomalies are induced by cytogenotoxic agents (AYLLON and GARCIA-VAZQUEZ, 2000; GRAVATO and SANTOS, 2002; VIEIRA et al., 2016). Results for nuclear abnormalities observed in B. iheringii are shown in table 2. In Caraá, significantly higher frequencies were observed in the winter in comparison with the summer, which could be related to the higher levels of lead and copper verified in the water in this sampling period. Comparing the two sampling sites in the same period, a significant higher level of abnormalities was observed in the summer in Parobé in comparison with Caraá, possibly due to the higher level of urbanization and industrial activities in the area. Accordingly, water samples collected in Parobé showed higher concentrations of metals (aluminum, iron and lead) when compared to Caraá, which could explain the higher frequency of damages observed in that local. Heavy metals are known to be toxic agents, capable of inducing DNA damage and cancer (VALKO et al., 2006; MATOS et al., 2017). Furthermore, Parobé is used for recreational purposes in the summer. Fish collected in Caraá in the winter exhibited a significant increase in nuclear abnormalities frequencies, whereas no significant differences were found in fish collected in Parobé.
Table 2 - Nuclear abnormalities frequencies per 1000 cells (mean \pm standard deviation) observerd in B. iheringii captured in December 2013 (summer) and July 2014 (winter) in two sampling sites in the Sinos River.

\begin{tabular}{cccc}
\hline Site & Summer & Winter & $\mathrm{p}$ \\
\hline Caraá & $0.80 \pm 0.53$ & $2.14 \pm 1.57$ & $0.01^{*}$ \\
Parobé & $2.40 \pm 1.82$ & $2.5 \pm 1.62$ & 0.94 \\
$\mathrm{p}$ & 0.009 & 0.77 & \\
\hline
\end{tabular}

Data are expressed as mean \pm standard deviation. Mean frequencies statistically different when $<0.05$.

Considering the comparison between sampling periods, the higher frequency of nuclear abnormalities observed in Caraá during winter, when compared to the frequencies found in summer, can also be related to the higher levels of lead and copper found in that sampling period. However, it should be pointed that fish demonstrate exposure effects for a long period of time. Therefore, for a more concrete relation between cause and effect, the continuous monitoring of metal concentrations, as well as other substances, in both sampling sites is of extreme importance, considering that these contaminants, when released in aquatic ecosystems, become a major threat to the organisms due to their toxicity and genotoxicity. Our data are in accordance to laboratory studies performed by other authors who have also reported cytogenotoxic damages induced by contaminants present in waters from urbanized regions (SCALON et al., 2010). Conversely, Bergamaschi et al. (2015) and Bianchi et al. (2015) have found no genotoxic effect in Leporinus obtusidens and Astyanax jacuhiensis, respectively, exposed under laboratory conditions to water samples collected at sites in the upper and middle sections of the Sinos River. Additionally, Lima et al. (2018) have also observed low frequencies of micronuclei in fish collected in areas impacted by agricultural activities.

Water physicochemical analyses evidenced some parameters above the reference values established by the CONAMA resolution 357/2005 for class I waters (Table 3). In the summer, Caraá presented BOD levels above the limits. Total phosphorous and lead were above the limits in Parobé in both sampling periods, whereas aluminum was detected above the limits only in the summer in this same site. BOD and total phosphorous are generally associated to the release of untreated sewage into water resources (BLUME et al., 2010). The sources of lead include disposal of urban solid waste that may contain batteries, electronics, material colored with lead paint, package labels, fuel additives and atmosphere (OLIVEIRA et al., 2008; BUENO-KRAWCZYK et al., 2015). Copper levels were above the reference levels in both sampling sites in the winter. Concentrations of iron exceeded the limits at both sampling sites and periods. Aluminum and iron may be present in water due to the release of untreated domestic sewage, solid waste disposal near the river and also to the typical soil composition of the 
Table 3 - Physicochemical parameters of the Sinos River water sampled at Caraá and Parobé in the summer (December 2013) and in the winter (July 2014).

\begin{tabular}{|c|c|c|c|c|c|}
\hline \multirow[t]{2}{*}{ Parameters } & \multicolumn{2}{|c|}{ Caraá } & \multicolumn{2}{|c|}{ Parobé } & \multirow[b]{2}{*}{ Reference Values ${ }^{a}$} \\
\hline & Summer & Winter & Summer & Winter & \\
\hline $\mathrm{BOD}\left(\mathrm{mg} \mathrm{O}_{2} / \mathrm{L}\right)$ & $7^{*}$ & $<0.5$ & 5 & $<0.5$ & 5 \\
\hline $\operatorname{coD}\left(\mathrm{mg} \mathrm{O}_{2} / \mathrm{L}\right)$ & 20.2 & 0.6 & 24.9 & 9.9 & - \\
\hline Total phosphorous (mg/L) & 0.1 & 0.03 & $0.14^{*}$ & $0.16^{*}$ & 0.1 \\
\hline Ammoniacal nitrogen $(\mathrm{mg} / \mathrm{L})$ & n.d. & n.d. & n.d. & n.d. & 3.7 \\
\hline Suspended solids (mg/L) & 5.5 & n.d. & 12 & 12.2 & - \\
\hline Aluminum (mg/L) & n.d. & n.d. & $0.758^{*}$ & n.d. & 0.1 \\
\hline Lead (mg/L) & n.d. & 0.008 & $0.021^{*}$ & $0.017^{*}$ & 0.01 \\
\hline Copper (mg/L) & n.d. & $0.018^{*}$ & n.d. & $0.012^{*}$ & 0.009 \\
\hline Total chromium (mg/L) & n.d. & n.d. & n.d. & n.d. & 0.05 \\
\hline Iron (mg/L) & 0.118 & 0.022 & $0.637^{*}$ & $2.179^{*}$ & 0.3 \\
\hline Nickel (mg/L) & 0.007 & 0.007 & 0.011 & 0.007 & 0.025 \\
\hline Zinc (mg/L) & 0.013 & 0.007 & 0.01 & 0.015 & 0.18 \\
\hline
\end{tabular}

aLimits according to CONAMA 357/2005 for Class I waters.

*Values in disagreement with established limits.

n.d.: not detected by the method.

region (ALLOWAY, 2013; BERGAMASCHI et al., 2015; KONZEN et al., 2015). Nickel and zinc values were within the limits at both sampling sites and periods whereas total chromium and ammoniacal nitrogen were not detected. Similar findings were observed by Dalzochio et al. (2018), where levels of aluminum and iron were also detected above the limits in Parobé.

Precipitation data did not show a great variation considering the comparison between sampling periods and sites. Caraá presented $183.4 \mathrm{~mm}$ and $175 \mathrm{~mm}$ in the summer and winter, respectively, whereas Parobé presented $130.3 \mathrm{~mm}$ and $119.8 \mathrm{~mm}$ in the summer and winter, respectively. The variation observed in precipitation rates does not seem to have caused effects in the biomarkers analyzed in the present study. The seasonality influence in micronuclei frequencies has been reported in previous studies, possibly due to its effects in pollutant concentrations However, Souza and Fontanetti (2006) observed a significant increase in micronuclei frequencies in the same fish species in sampling periods presenting dry and cold weather conditions with water samples from Paraíba do Sul river, São Paulo, indicating influence of seasonality and precipitation. Conversely,-some studies do not demonstrate this influence (WIRZINGER et al., 2007, BOLOGNESI and HAYASHI, 2011). Sampling periods with less rainfall favor the occurrence of high levels of chemicals in water resources, whereas periods with high pluviosity favor the dilution of pollutants. However, rainfall can worsen pollution effects through a greater leaching of chemicals retained in soil or sewer systems (DUARTE et al., 2012).

\section{Conclusions}

The present study evidenced higher DNA damage and levels of metals in Parobé, where higher urbanization and industrial activities are observed. However, precipitation rates did not influence in the frequency of damages. Moreover, the fish specie used was sensitive to the cytotoxicity test and could be used in further biomonitoring studies.

\section{Acknowledgment}

This work was partially supported by research grants from Fundação de Amparo à Pesquisa do Estado do Rio Grande do Sul (FAPERGS/PQG - number 2008-2551/132), Conselho Nacional de Desenvolvimento Científico e Tecnológico (CNPq) and Universidade Feevale. 


\section{References}

ALLOWAY BJ. Heavy metals in soils. Trace metals and metalloids in soils and their bioavailability. 3rd ed. Netherlands: Springer Netherlands; 2013.

AL-SABTI K. Handbook of genotoxic effects and fish chromosomes. 1st ed. Ljubljiana: J. Stefan Institute; 1991.

AL-SABTI K, METCALFE CD. Fish micronuclei for assessing genotoxicity in water. Mutat. Res. 1995;343(23):121-135.

AKAISHI FM, SILVA DE ASSIS HC, JAKOBI SCG, EIRAS-STOFELLA DR, ST-JEAN SD, COURTENAY SC et al. Morphological and neurotoxicological fi ndings in tropical freshwater fi sh (Astyanax sp.) after waterborne and acute exposure to water soluble fraction (WSF) of crude oil. Arch. Environ. Contam. Toxicol. 2004;46(2):244-253.

AMERICAN PUBLIC HEALTH ASSOCIATION, American Water Works Association, Water Environmental Federation. Standard Methods for the Examination of Water and Wastewater. Washinton: APHA - American Public Health Association, 2005.

AYLLÓN F, GARCIA-VAZQUEZ E. Induction of micronuclei and other nuclear abnormalities in European minnow Phoxinus phoxinus and mollie Poecilia latipinna: an assessment of the fish micronucleus test. Mutat. Res. 2000;467(2):177-186.

BERGAMASCHI B, RODRIGUES MT, SILVA JVS, KLUGE M, LUZ RB, FLECK JD et al. Moving beyond classical markers of water quality: detection of enteric viruses and genotoxicity in water of the Sinos River. Braz J Biol. 2015;75(2):63-67.

BIANCHI E, GOLDONI A, TRINTINAGLIA L, LESSING G, SILVA CEM, NASCIMENTO CA et al. Evaluation of genotoxicity and cytotoxicity of water samples from the Sinos River Basin, southern Brazil. Braz. J. Biol. 2015;75(2):68-74.

BLUME KK, MACEDO JC, MENEGUZZI A, SILVA LB, QUEVEDO DM, RODRIGUES MAR. Water quality assessment of the Sinos River, Southern Brazil. Braz. J. Biol. 2010;70(4):1185-1193.

BOLOGNESI C, HAYASHI M. Micronucleus assay in aquatic animals. Mutagenesis. 2011;26(1):205-213.

BRITSKI HA, SATO Y, ROSA ABS. Manual de identificação de peixes da região de Três Marias, com chave e identificação para os peixes da bacia do Rio São Francisco. Brasília: Ministério da Irrigação - CODEVASF; 1998.

BRUNETTI R, MAJONE F, GOLA I, BELTRAME C. The micronucleus test: examples of application to marine ecology. Mar. Ecol. Prog. Ser. 1988;44(1):65-68.
BÜCKER A, CARVALHO W, ALVES-GOMES JA. Avaliação da mutagênese e genotoxicidade em Eigenmannia virescens (Teleostei: Gymnotiformes) expostos ao benzeno. Acta Amaz. 2006;36(3):357-364.

BUENO-KRAWCZYK ACD, GUILOSKI IC, PIANCINI LDS, AZEVEDO JC, RAMSDORF WA, IDE AH et al. Multibiomarker in fish to evaluate a river used to water public supply. Chemosphere. 2015;(135):257-264.

BÜHLER D, MARINOWIC DR, RODRIGUES MAS, SILVA LB. Evaluation of genotoxicity and cytotoxicity of treated tannery wastewater in Southern Brazil. Int. J. Environ. Tech. Manag. 2012;15(2):114-123.

CARRASCO KR, TILBURY KL, MAYERS MS. Assessment of the piscine micronuclei test as in situ biological indicator of chemical contaminants effects. Can. J. Fish. Aquat. Sci. 1990;47(11):2123-2136.

ÇAVAS T, ERGENE-GOZUKARA S. Evaluation of the genotoxic potential of lambda-cyhalothrin using nuclear and nucleolar biomarkers on fish cells. Mutat. Res. 2003;534(1-2):93-99.

COSTA PF, SCHULZ UH. The fish community as na indicator of biotic integrity of the streams in the Sinos River basin, Brazil. Braz. J. Biol. 2010;70 Suppl 4:11951205.

DALZOCHIO T, SIMÕES LAR, SOUZA MS, RODRIGUES GZP, PETRY IE, ANDRIGUETTI NB et al. Water quality parameters, biomarkers and metal bioaccumulation in native fish captured in the Ilha River, southern Brazil. Chemosphere. 2017;189:609-618.

DALZOCHIO T, RODRIGUES GZP, SIMÕES LAR, SOUZA MS, PETRY IE, ANDRIGUETTI NB et al. In situ monitoring of the Sinos River, southern Brazil: water quality parameters, biomarkers, and metal bioaccumulation in fish. Environ. Sci. Pollut. Res. 2018;25(10):9485-9500.

DUARTE ID, DIAS MC, DAVID JAO, MATSUMOTO ST. A qualidade da água da Lagoa Jacuném (Espírito Santo, Brasil) em relação a aspectos genotóxicos e mutagênicos, mensurados respectivamente pelo ensaio do cometa e teste do micronúcleo em peixes da espécie Oreochromis niloticus. R. Bras. Bioci. 2012;10(2):211-219.

EGITO LCM, MEDEIROS MD, DE MEDEIROS SRB, AGNEZ-LIMA LF. Cytotoxic and genotoxic potential of surface water from the Pitimbu river, northeastern/ RN Brazil. Genet. Mol. Biol. 2007;30(2):435-441.

FIGUEIREDO JAS, DRUMM E, RODRIGUES MAS, SPILKI FR. The Rio dos Sinos watershed: an economic and social space and its interface with environmental status. Braz. J. Biol. 2010;70(4):1131-1136. 
FLORA S, VIGÁRIO L, D’AGOSTINI E, CAMOIRANO A, BAGNASCO M, BENNICELLI C et al. Multiple genotoxicity biomarkers in fish exposed in situ to polluted river water. Mutat. Res. 1993;319(3):167-177.

FLOREA AM, BUSSELBERG D. Occurrence, use and potential toxic effects of metals and metal compounds. Biometals. 2006;19(4):419-427.

FUNDAÇÃO ESTADUAL DE PROTEÇÃO AMBIENTAL HENRIQUE LUIS ROESSLER - FEPAM. Qualidade das águas do Rio dos Sinos: monitoramento da qualidade de água. Porto Alegre. 1999.

GOLDONI A, GOLFETO C, TEIXEIRA JB, BLUMM G, WILHELM CM, TELÖKEN F et al. Cytotoxic and genotoxic evaluation and chemical characterization of sewage treated using activated sludge and a floating emergent-macrophyte filter in a municipal wastewater treatment plant: a case study in Southern Brazil. Environ. earth sci. 2014;72(5):1503-1509.

GRAVATO C, SANTOS MA. $\beta$-Naohthiflavone liver EROD and erytrocytic nuclear abnormality induction in juvenile Dicentrarchus labrax. Ecotoxicol. Environ. Saf. 2002;52(1):69-74.

HOSHINA MM, ANGELIS DF, MARIN-MORALES MA. Induction of micronucleus and nuclea ralterations in fish (Oreochromis niloticus) bya petroleum refinery effluent. Mutat. Res. 2008;656(1-2):44-48.

KIRSCHBAUM AA, SERIANI R, RANZANI-PAIVA MJT, ABESSA DMS, PEREIRA CDS. Cytogenotoxicity biomarkers in fat snook Centropomus parallelus from Cananéia and São Vicente estuaries, SP. Genet. Mol. Biol. 2009;32(1):151-154.

KONZEN GB, FIGUEIREDO JAS, QUEVEDO DM. History of water quality parameters - a study on the Sinos River/Brazil. Braz. J. Biol. 2015;75(2):1-10.

LEMOS CT, RODEL PM, TERRA NR, OLIVEIRA NCD, ERDTMANN B. River water genotoxicity evaluation using micronucleus assay in fish erythrocytes. Ecotoxicol. Environ. Saf. 2007;66(3):391-401.

LIMA LBD, MORAIS PB, ANDRADE RLT, MATTOS LV, MORON SE. Use of biomarkers to evaluate the ecological risk of xenobiotics associated with agriculture. Environ. Pollut. 2018;237:611-624.

MATOS LA, CUNHA AC, SOUZA AA, MARANHÃO JP, SANTOA NR, GONÇALVES MMC et al. The influence of heavy metals on toxicogenetic damage in a Brazilian tropical river. Chemosphere. 2017;185:852-859.

OHE T, WATANABE T, WAKABAYASHI K. Mutagens in surface waters: a review. Mutat. Res. 2004;567(2-3):109-149.
OLIVEIRA MTG, ROLIM SBA, MELLO-FARIAS PC, MENEGUZZI A, LUTCKMEIER C. Industrial pollution of environmental compartments in the Sinos River Valley, RS, Brazil: geochemical-biogeochemical characterization and remote sensing. Water Air Soil Pollut. 2008;192(14):183-198.

PACHECO M, SANTOS MA. Induction of liver EROD and erythrocytic nuclear abnormalities by cyclophosphamide and PAHs in Anguilla anguilla L. Ecotoxicol. Environ. Saf. 1998;40(1-2):71-76.

PANTALEÃO SM, ALCÂNTARA AV, ALVES JPH, SPANÓ MA. The piscine micronucleus test to assess the impact of pollution on the Japaratuba river in Brazil. Environ. Mol. Mutagen. 2006;47(3):219-224.

PETRY AC, SCHULZ UH. Longitudinal changes and indicator species of the fish fauna in the subtropical Sinos River, Brazil. J. Fish. Biol. 2006;69(1):272-290.

RAND GM. Fundamentals of Aquatic Toxicology: effects, environmental fate and risk assessment. Washington: CRCPress; 1995.

SÁNCHEZ-GALÁN S, LINDE AR, IZQUIERDO JI, GARCÍA-VÁSQUEZ E. Micronuclei and fluctuating asymmetry in brown trout (Salmo trutta): complementary methods to biomonitor freshwater ecosystems. Mutat. Res. 1998;412(3):219-225.

SCALON MCS, RECHENMACHER C, SIEBEL AM, KAYSER ML, RODRIGUES MT, MALUF SW et al. Evaluation of Sinos River water genotoxicity using the comet assay in fish. Braz. J. Biol. 2010;70(4):12171222 .

SERIANI R, ABESSA DMS, KIRSCHBAUM AA, PEREIRA CDS, RANZANI-PAIVA MJT, ASSUNÇÃO A et al. Water toxicity and cyto-genotoxicity biomarkers in the fish Oreochromis niloticus (CICHLIDAE). J. Braz. Soc. Ecotoxicol. 2012;7(2):67-72.

SIDDIQUI AH, AHMAD M. The Salmonella mutagenicity of industrial, surface and ground water samples of Aligarh region of India. Mutat. Res. 2003;541(1-2):21-29.

SILVA J, HEUSER V, ANDRADE V. Biomonitoramento Ambiental. In: Silva J, Erdtmann B, Henriques J.A.P. Genética Toxicológica. Porto Alegre: Alcance; 2003. p. 167-178.

SOUZA TS, FONTANETTI CS. Micronucleus test and observation of nuclear alterations in erythrocytes of Nile tilapia exposed to waters affected by refinery effluent. Mutat. Res. 2006;605(1-2):87-93.

UDROIU I. The micronucleus test in piscine erythrocytes. Aquat. Toxicol. 2006;79(2):201-204. 
VALKO M., RHODES CJ, MONCOL J, IZAKOVIC M, MAZUR M. Free radicals, metals and antioxidants in oxidative stress-induced cancer. Chem. Biol. Interact. 2006;160(1):1-40.

VIEIRA CED, COSTA PG, LUNARDELLI B, OLIVEIRA LF, CABRERA LC, RISSO WE et al. Multiple biomarker responses in Prochilodus lineatus subjected to shortterm in situ exposure to streams from agricultal areas in Southern Brazil. Sci. Total. Environ. 2016;542:44-56.

WIRZINGER G, WELTJE L, GERCKEN J, SORDYL $\mathrm{H}$. Genotoxic damage in field collected three-spined sticklebacks (Gasterosteus aculeatus L.): a suitable biomonitoring tool?. Mutat. Res. 2007;628(1):19-30. 